\title{
The Influence of Electromagnetic Field on Viability of Marine Microalgae Tetraselmis Suecica and Bacteria Escherichia Coli and Enterococcus Faecalis
}

\section{Utjecaj elektromagnetskog polja na održivost morske mikroalge vrste Tetraselmis Suecica i bakterije Escherichia Coli i Enterococcus Faecalis}

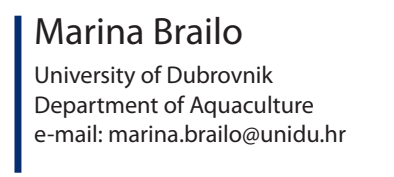

\author{
Marijana Pećarević \\ University of Dubrovnik \\ Department of Aquaculture \\ e-mail: marijana.pecarevic@unidu.hr
}

Dinka Lale
Energy and Information
Technology Agency, Dubrovnik
e-mail: dinka.vragolov@energit.biz

\author{
Dolores Grilec \\ Department of Environmental Health \\ Public Health Institute of the \\ Dubrovnik-Neretva County \\ e-mail: dolores.grilec@zzjzdnz.hr
}

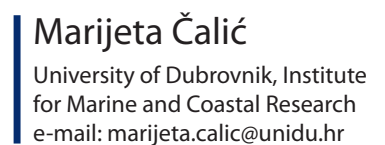

Mato Mišković

Dubrovnik Hydro Power Plant University of Dubrovnik, Electrical

Engineering and Computing Department e-mail:Mato.Miskovic@hep.hr

\section{Josip Mikuš \\ University of Dubrovnik \\ Department of Aquaculture \\ e-mail:jmikus@unidu.hr}

\author{
Ana Bratoš Cetinić \\ University of Dubrovnik \\ Department of Aquaculture \\ e-mail: abratos@unidu.hr
}

DOI $10.17818 / \mathrm{NM} / 2018 / 2.2$

UDK 616-092.7 573.4

Original scientific paper / Izvorni znanstveni rad Paper accepted / Rukopis primljen: 24. 1. 2018.

\section{KEY WORDS}

microorganisms magnetic treatment conductivity

A number of laboratory electromagnetic field tolerance experiments with the selected organisms was performed; each microorganism was treated for various lengths of time; 1, 5 and 10 minutes, and in three various media with special regards to the conductivity. Bacteria were exposed to high, moderate and extremely low conductivity media, and the microalgae to high, low and extremely low conductivity media. The microbial viability was checked by counting the bacterial colony forming units, as well as alive and dead stained microalgae cells. It was found that the time of exposure to the EMF had a profound effect on the viability of $T$. suecica only in the extremely low conductivity media, and that it did not affect the viability of $E$. coli or E. faecalis at all.

\section{Sažetak}

Cilj ovoga istraživanja bio je utvrditi može li elektromagnetsko polje (EMP) frekvencije 50 $\mathrm{Hz}$ i magnetske indukcije od 0,25 T uspješno inaktivirati jednu morsku fitoplanktonsku vrstu; mikroalgu Tetraselmis suecica te dvije vrste bakterija; Escherichia coli i Enterococcus faecalis. Provedeni su laboratorijski pokusi tolerancije odabranih organizama na elektromagnetsko polje. Svaki mikroorganizam tretiran je u različitim razdobljima; 1, 5 i 10 minuta, te u tri različita medija s obzirom na vodljivost. Bakterije su bile izložene u mediju visoke, umjerene i ekstremno niske vodljivosti, a mikroalge u mediju visoke, niske i ekstremno niske vodljivosti. Mikrobna vijabilnost je ispitivana uz pomoć brojanja izraslih kolonija bakterija, te živih i mrtvih obojenih stanica mikroalgi. Utvrđeno je da je vrijeme izlaganja elektromagnetskom polju imalo velik utjecaj na vijabilnost T. suecica samo u mediju ekstremno niske vodljivosti i da nije uopće utjecalo na vijabilnost $E$. coli ili E. faecalis.

\section{INTRODUCTION / Uvod}

Many researchers have focused on exploring various methods for inactivation of various microorganisms involving the effect of magnetic fields. Some researched the application of pulsed magnetic field for bacterial sterilization [16], or combat biofouling
[23], whereas others studied the magnetic field effect on bacteria for possible application in dentistry due to its bactericidal activity and oral pathogen inactivation [32]. There is a patent for a magnetic apparatus for controlling Protista in distillates [15] and 
a method for the magnetic inhibition of Protista [7] whereat the algae, bacteria, fungi and protozoans were included, as well as for a method for electromechanical lysing of algae cells [10] in a lysing medium comprising fresh water, salt water, brackish water, growth medium, culture medium or combinations thereof.

Electromagnetic field (EMF) exposure has obvious advantages over other methods for inactivation of microorganisms. Due to a comparatively short exposure time required to exploit EMF effect on microorganisms, it makes it easily applicable in many various facilities concerning sterilization of various liquids. In addition, the fact that the medium's composition remains unchanged after the EMF treatment makes for an environmentally very friendly method and opens a window of opportunities for its application in inactivation of microorganisms in various types of fluids such as ballast water.

Ballast water provides stability and maneuverability to the ship during its voyage and is commonly taken on at one port when cargo is unloaded, and discharged at another port when the ship receives cargo. Thereby the water contains a variety of organisms including bacteria and viruses, as well as the adult and larval stages of the numerous marine and coastal species; those are transported from their native range to distant areas where these species are then called non-native or non-indigenous species [2]. Given suitable conditions, some non-native species may become invasive and have a serious ecological, economic and public health impact on the receiving environment [2]. Once established in a new region, non-native species may invade wider areas and displace native organisms completely. Inactivation of organisms in ballast water during the voyage is the critical point in control and prevention of the unwanted introductions [4]. A number of methods and technologies for ballast water treatment have been developed during the last few decades and they could roughly be classified as mechanical (cyclonic separation, filtration, etc.), chemical (use of biocides, chlorine, ozone, advanced oxidation process, etc.) and physical (heating, cooling,
UV radiation, ultrasound, etc.) [28, 31, 17]. No single technique has been able to remove all types of organisms from ballast tanks, making it a great challenge for researchers around the world to find a technique that is effective in reducing introductions, environmentally friendly and acceptable to the shipping industry in terms of safety, time and cost.

Considering all of the above, we wanted to determine whether the strong electromagnetic field of $50 \mathrm{~Hz}$ frequency could be successful in inactivation of selected microorganisms if applied for a short exposure time and therefore suitable as a ballast water treatment option. In order to investigate this a number of laboratory electromagnetic field tolerance experiments of the marine microalgae Tetraselmis suecica and two bacteria strains; Escherichia coli and Enterococcus faecalis were performed.

\section{MATERIAL AND METHODS / Materijal i metode 2.1. Treating device / Uređaj za tretiranje}

In order to investigate the effect of electromagnetic field on microorganisms that are present in the ships' ballast water, an appropriate device is necessary. We designed a device that generated an electromagnetic field using a frequency used in ships' electrical network and with comparatively low power consumption (Figure 1). It was an electrical transformer made of 190 windings of copper coil around an iron core connected to the common electrical network with frequency of $50 \mathrm{~Hz}$ and the voltage of $212 \mathrm{~V}$ measured by YF-3170 multimeter (Yu Fong Electronics, Taipei Hsien, Taiwan). At one side of the device there was a rectangular gap $(0.08 \mathrm{~m} \times 0.07 \mathrm{~m})$ in the iron core where the samples were placed and where a specific homogenous electromagnetic field with basic harmonic sine shape was generated. Using the Hall Effect Gaussmeter (Model 5170, F.W. Bell, Sypris, Pacific Scientific, OECO LLC, Portland, USA) the value of the magnetic induction in that gap was measured to $(0.25 \pm 0.01) \mathrm{T}$.

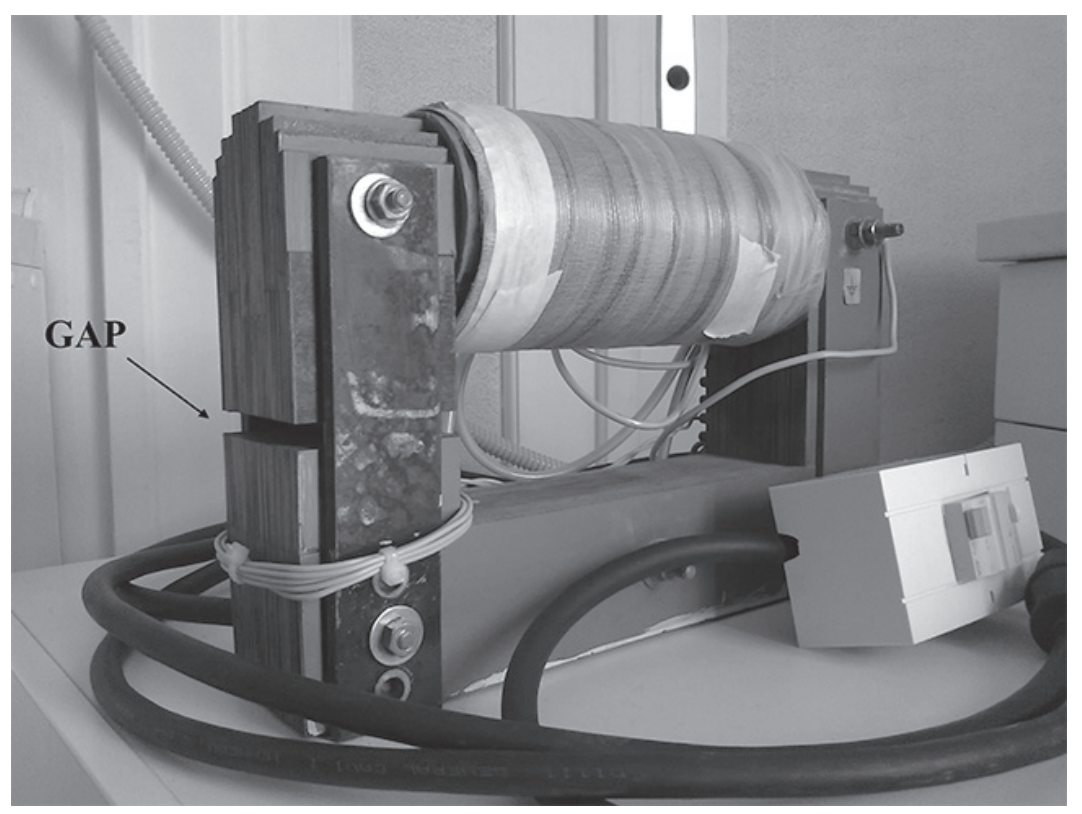

Figure 1 The treating device - the electrical transformer that uses electricity of $212 \mathrm{~V}$ and frequency of $50 \mathrm{~Hz}$ and generates a specific homogenous electromagnetic field with basic harmonic sine shape and the magnetic induction of $0.25 \mathrm{~T}$.

Slika 1. Uređaj za tretiranje - električni transformator koji koristi električnu energiju od $212 \mathrm{~V}$ i frekvencije od $50 \mathrm{~Hz}$ i generira specifično homogeno elektromagnetsko polje s osnovnim harmonijskim sinusnim oblikom i magnetskom indukcijom od 0.25 T. 


\subsection{Experimental procedure / Eksperimentalna procedura}

The experiment was carried out in the same way for all the microorganisms. A Petri dish containing $8 \mathrm{~mL}$ of the culture was placed in the gap of the treating device and the device was turned on exposing the sample to $50 \mathrm{~Hz}$ EMF of $0.25 \mathrm{~T}$. After the experiment the temperature of the samples was measured. Control samples were obtained by placing the microorganisms in the gap without turning the device on, thus not exposing them to the electromagnetic field. Each microorganism was tested for the three different exposure times (1,5 and $10 \mathrm{~min}$ ) in three various growth media with special regards to the conductivity and every experiment was carried out in triplets. Respectively, 27 samples of each microorganism exposed to the EMF and the same number of the ones used as control was analyzed.

\subsubsection{Microalgae / Mikroalge}

In this experiment the marine green microalgae Tetraselmis suecica (Kylin) Butcher, 1959 was used. The CCAP 66/4 strain was obtained from the Culture Collection of Algae and Protozoa of the Scottish Marine Institute (Oban, United Kingdom) and provided from the shellfish hatchery unit of The Mariculture Business and Innovation Centre of the University of Dubrovnik (Ston, Croatia).

The viability of this phytoplankton species was checked by enumeration of cells stained with fluorescein diacetate (FDA) dissolved in dimethylsulfoxide (DMSO) [14], [9], [24]. An Olympus IX71 inverted research microscope equipped with the reflected fluorescence system (excitation wavelength of 460-490 nm by a $50-W$ mercury lamp and observation filtered wavelength of 520-700 nm) was used to observe simultaneous green and red fluorescence of the stained samples. The enumeration was performed three times; whereat a minimum of 100 cells were counted each time.

For the EMF exposure treatment, phytoplankton samples in three different growth media were used. The first one was the original sample of the culture stained for viability determination, referred further as growth media with high conductivity value (TS-H), and the following two were prepared by diluting this sample with glycerol (Kemika, Zagreb, Croatia), resulting in low (TS-L) and an extremely low (TS-EL) conductivity growth media. The different parameters of $T$. suecica media determined by the portable multi-parameter instrument (Multi 350i; WTW, Weilheim, Germany) are shown in Table 3. After the exposure to the electromagnetic field T. suecica alive and dead cells were enumerated again.

\subsubsection{Bacteria / Bakterije}

All the experiments with bacteria were performed in the laboratory of The Department of Environmental Health, Public Health Institute of the Dubrovnik - Neretva County. In these experiments the following strains obtained from the American Type Culture Collection (ATCC) (Manassas, USA) were used: Enterococcus faecalis ATCC 29212 and the Escerichia coli ATCC 25922.

The bacteria were harvested in Trypticase Soy Agar (Biolife, Milan, Italy) liquid medium and incubated at $37{ }^{\circ} \mathrm{C}$ for $24 \mathrm{~h}$ without shaking. Following the incubation, bacterial cultures were consecutively diluted in a saline solution prepared by dissolving $9 \mathrm{~g} \mathrm{NaCl}$ (Kemika) in $1 \mathrm{~L}$ of demineralised water (Millipore Elix 10 water purification system, EMD Millipore Corporation, Billerica, USA). In order to determine the number of bacterial colony forming units (CFU) in each dilution, portions of $5 \mathrm{~mL}$ were filtered through membrane filters with pore size of $0.45 \mu \mathrm{m}$, placed on selective Slanetz Bartley agar (Biolife) plates and incubated at $37{ }^{\circ} \mathrm{C}$. After four hours filters of E. coli culture were transferred to Tryptic Bile Agar (Biolife) plates and incubated at $44{ }^{\circ} \mathrm{C}$ for $20 \mathrm{~h}$, followed by the indole test and enumeration of CFU. After $48 \mathrm{~h}$ at $37{ }^{\circ} \mathrm{C}$ filters of $E$. faecalis culture were transferred on Bile Aesculin Azide agar (Biolife) plates preheated to $44{ }^{\circ} \mathrm{C}$ and incubated for $2 \mathrm{~h}$, followed by enumeration of CFU.

Based on the CFU numbers, the appropriate concentration for the EMF exposure experiments was selected and new dilutions of each bacterium in three types of growth media with special regards to the conductivity were prepared. Various parameters of bacterial growth media were measured by portable $\mathrm{pH}$ meter (WTW 340i; WTW) and conductivity meter (Handylab LF 11; SCHOTT Instruments, Mainz, Germany) resulting with $E$. coli high $(E C-H)$, moderate (EC-M) and extremely low (EC-EL) conductivity growth media (Table 1) and E. faecalis high (EF-H), moderate (EF-M) and extremely low (EFEL) conductivity growth media (Table 2). After the EMF exposure the bacterial CFU numbers were determined again. To make sure that there was no contamination with $E$. faecalis or E. coli during the procedure, we also conducted an experiment using uninoculated growth media as blanks.

Table 1 Escherichia coli growth media parameters Tablica 1. Parameteri uzgojnog medija za bakteriju Escherichia coli

\begin{tabular}{|c|c|c|c|}
\hline Medium / Parameter & EC-H & EC-M & EC-EL \\
\hline Conductivity $(\mathrm{mS} / \mathrm{cm})$ & 53.600 & 14.230 & 0.005 \\
\hline Salinity $(\mathrm{psu})$ & 39.5 & 8.8 & 0.0 \\
\hline Temperature $\left({ }^{\circ} \mathrm{C}\right)$ & 23.2 & 22.9 & 23.0 \\
\hline $\mathrm{pH}$ & 7.2 & 6.9 & 7.1 \\
\hline
\end{tabular}

E. coli high conductivity growth medium (EC-H), E. coli moderate conductivity growth medium (EC-M), E. coli extremely low conductivity growth medium (EC-EL).

Uzgojni medij jake vodljivosti za E. coli (EC-H), uzgojni medij srednje vodljivost za E. coli (EC-M), uzgojni medij ekstremno niske vodljivosti za $E$. coli (EC-EL).

Table 2 Enterococcus faecalis growth media parameters Tablica 2. Parameteri uzgojnog medija za bakteriju Enterococcus faecalis

\begin{tabular}{|c|c|c|c|}
\hline Medium / Parameter & EF-H & EF-M & EF-EL \\
\hline Conductivity $(\mathrm{mS} / \mathrm{cm})$ & 52.600 & 14.850 & 0.001 \\
\hline Salinity $(\mathrm{psu})$ & 38.1 & 9.4 & 0.0 \\
\hline Temperature $\left({ }^{\circ} \mathrm{C}\right)$ & 23.2 & 22.9 & 23.0 \\
\hline $\mathrm{pH}$ & 7.1 & 7.2 & 6.8 \\
\hline
\end{tabular}

E. faecalis high conductivity growth medium (EF-H), E. faecalis moderate conductivity growth medium (EF-M), E. faecalis extremely low conductivity growth medium (EF-EL).

Uzgojni medij jake vodljivosti za E. faecalis (EF-H), uzgojni medij srednje vodljivost za E. faecalis (EF-M), uzgojni medij ekstremno niske vodljivosti za E. faecalis (EF-EL). 
Table 3 Tetraselmis suecica growth media parameters Tablica 3. Parameteri uzgojnog medija za mikroalgu Tetraselmis suecica

\begin{tabular}{|c|c|c|c|}
\hline Medium / Parameter & TS-H & TS-L & TS-EL \\
\hline Conductivity $(\mathrm{mS} / \mathrm{cm})$ & 50.700 & 0.265 & 0.007 \\
\hline Salinity $(\mathrm{psu})$ & 32.8 & 0.0 & 0.0 \\
\hline Temperature $\left({ }^{\circ} \mathrm{C}\right)$ & 22.9 & 22.7 & 22.8 \\
\hline $\mathrm{pH}$ & 7.3 & 7.2 & 7.3 \\
\hline
\end{tabular}

T. suecica high conductivity growth medium (TS-H), T. suecica low conductivity growth medium (TS-L), T. suecica extremely low conductivity growth medium (TS-EL).

Uzgojni medij jake vodljivosti za T. suecica (TS-H), uzgojni medij niske vodljivosti T. suecica (ST-L), uzgojni medij ekstremno niske vodljivosti $T$. suecica (TS-EL).

\subsection{Statistical analysis / Statistička analiza}

Statistical analysis of the obtained results was performed using variance analysis (ANOVA), at the assumed accuracy level $(p<0.05)$. Analysis of the differences between means from the particular group was completed using post hoc Tukey's test.

\section{RESULTS AND DISCUSSION / Rezultati i rasprava 3.1. Effect of the exposure time on sample temperature / Utjecaj vremena izlaganja na temperaturu uzorka}

During a $1 \mathrm{~min}$ treatment the sample temperature remained the same, during $5 \mathrm{~min}$ it increased by $1{ }^{\circ} \mathrm{C}$ and during $10 \mathrm{~min}$ exposure we noticed an increase in $2{ }^{\circ} \mathrm{C}$ in all treated samples. Since the maximum temperature of all the samples after the exposure experiment was recorded to be $25.2{ }^{\circ} \mathrm{C}$, hazardous thermal effects of EMF on the treated microorganisms were ruled out.

\subsection{Effect of the exposure time and the conductivity of the medium on viability of Tetraselmis suecica / Utjecaj vremena izlaganja i vodljivosti medija na vijabilnost alge Tetraselmis suecica \\ One-way ANOVA showed a statistically significant difference} among the numbers of alive T. suecica cells in control and treated groups ( $p=0.000, F=209.88$ ) as well as between the number of dead T. suecica cells in control and treated groups $(p=0.000$, $F=209.88$ ). Further analysis by Post hoc Tukey's test showed no significant difference between control and all treated samples in TS-H and TS-L groups. Also, in TS-EL samples no statistically significant difference between time of exposure of 1 and $5 \mathrm{~min}$. was found. However, TS-EL samples treated for $10 \mathrm{~min}$. were significantly different compared to all other samples. In control samples alive cells accounted for $83 \%$ of the total cell number, and in the treated ones, for only $51 \%$ (Figure 2). In addition, there was no statistically significant difference between the number of alive cells in control samples enumerated at the moment of the glycerol addition and $10 \mathrm{~min}$ after which eliminates glycerol as the cause of $32 \%$ increase in mortality of $T$. suecica in the treated sample.

These results support the ideas of previous research $[22,21$, 27] concerning the mechanism of action of EMF on cells. Counts of alive and dead cells of $T$. suecica exposed to the $50 \mathrm{~Hz}$ EMF of $0.25 \mathrm{~T}$ in high and low conductivity media imply that neither the time of exposure nor the conductivity of the media had any effect on the viability of these phytoplankton organisms. In extremely low conductivity medium different results for different

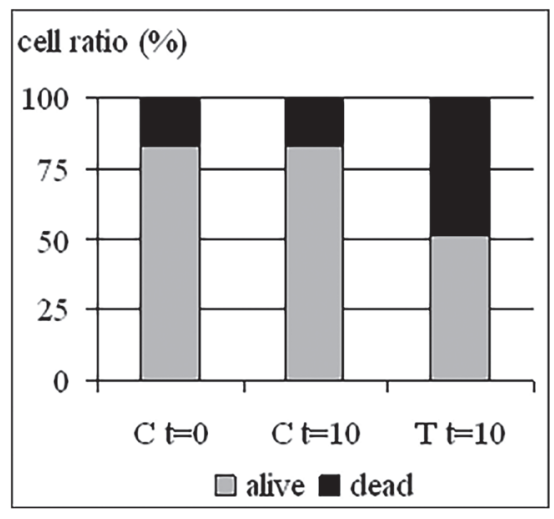

Figure 2 The ratio of alive and dead T. sueccica cells in extremely low growth medium. The cells were enumerated in control samples immediately after adding the glycerol $(\mathrm{C}=0)$ and after 10 minutes $(C t=10)$ and in the treated samples after $10(T t=10)$ minutes of exposure to the $50 \mathrm{~Hz}$ and $0.25 \mathrm{~T}$ electromagnetic field in extremely low conductivity medium.

Slika 2. Omjer živih i mrtvih stanica T. sueccica u uzgojnom mediju ekstremno niske vodljivosti. Stanice su prebrojavane u kontrolnim uzorcima neposredno nakon dodavanja glicerola (C $t=0)$ i nakon 10 minuta $(C t=10)$ te u tretiranim uzorcima nakon 10 minuta izlaganja $50 \mathrm{~Hz}$ electromagnetskom polju $0.25 \mathrm{~T}$ u mediju ekstremno niske vodljivosti.

exposure times were recorded; the exposure in duration of 1 and $5 \mathrm{~min}$ did not have any effect on the number of either alive or dead cells in control and treated samples, but the 10 minute exposure reduced the proportion of alive cells by $32 \%$. This fact, combined with the fact that glycerol was excluded as the cause of $T$. suecica mortality, suggests that the effect of exposure time is significant only in the medium almost free of other ions, where membrane's ions, when given enough time, can upset its potential and cause damage to the cell. The time as an important factor has already been recognized [21]. In addition, the presence of ions in the medium is another important factor highlighted in the method for electromechanical lysing of different species of algae, including T. suecica [10] in a lysing medium comprised of fresh water, salt water, brackish water, growth medium, culture medium or combinations thereof. A research with Staphylococcus aureus exposure to a lowfrequency electric and electromagnetic field $(20 \mathrm{~Hz}, 5 \mathrm{mT})$ in fluid and on gel-like medium [19] also supports these findings. The observed growth inhibition effects in fluid medium and the fact that no impact of applied electric and magnetic field was found in gel-like medium, imply that the unlimited mobility of ions is the basic requirement for field-induced effects in fluids. A study of indirect effects of EMF on E. coli through water, assay buffer, or peptone growth medium [30] also supports these findings. Researchers observed different EMF effects on bacterial growth; 70.6 and $73 \mathrm{GHz}$ similarly suppressed the $E$. coli growth in water and on solid medium, and the growth depression for 51.8 and $53 \mathrm{GHz}$ was less in suspension then on solid medium, especially for $53 \mathrm{GHz}$. The authors related these differences, in relation to a specific frequency, with the EMF energy partial absorbance by the surrounding medium. This implies that if there are ions present in the medium and if they are mobile, they can take on some of the magnetic field effect providing shielding effect to the microorganisms grown in that medium. It is notable that this finding corresponds with the shielding effect claimed for whole 
organisms; the conductivity of their bodies shields the interior of the body from external electromagnetic fields, especially at low frequencies [8].

A lack of scientific research regarding different effects of EMF exposure on Tetraselmis sp. as microalgae of interest was noticed in literature. Studies of EMF effects to other phytoplankton species are diverse, including reports of negative to positive effect assigned to its influence on different molecular interaction sites such as cell membrane, chloroplast, nucleus/DNA, proteins, protoplasm and a whole cell causing either negative or positive effect [12].

\subsection{Effect of the exposure time and the conductivity of the medium on bacterial CFU / Utjecaj vremena izlaganja i vodljivosti medija na BIK bakterija}

The enumeration of bacterial CFU in uninoculated growth media showed no results, implying that during the experimental procedure there was no contamination with E. coli or E. faecalis.

The bacterial CFU numbers in control and treated groups were not influenced by the exposure time or its interaction effect with conductivity. Two-way ANOVA showed a statistically significant difference between the number of $E$. coli CFU in control and treated groups $(p=0.000 ; F=31.19)$, as well as a statistically significant difference between the number of $E$. faecalis CFU in control and treated groups $(p=0.000 ; F=15.02)$ only with regards to the conductivity of the growth medium. Further analysis of the number of $E$. coli CFU in different growth media by One-way ANOVA showed a statistically significant difference $(p=0.000 ; F=30.80)$ and Post hoc Tukey's test specified that the CFU number in samples in EC-EL growth medium was not significantly different from the CFU number in samples in EC-M growth medium and that both of them were significantly higher than the CFU number in samples in EC-H growth medium (Figure 3). Similarly, further analysis of the number of E. faecalis CFU in different growth media by
One-way ANOVA showed a statistically significant difference $(p=0.000 ; F=13.09)$ and Post hoc Tukey's test specified that the CFU number in samples in the EF-H growth medium was not significantly different from the CFU number in samples in EF-M growth medium and that both of them were significantly lower than the CFU number in samples in EF-EL growth medium (Figure 4).

In experiments with E. coli and E. faecalis, the time of exposure to the magnetic field did not at any point have an effect on the number of bacterial CFU in control and treated samples, but conductivity of the growth medium did cause a statistically significant difference. The most negative effect of EMF on bacteria was found in high conductivity growth media, which is contrary to the finding of the most negative effect on $T$. suecica in extremely low conductivity growth media. This could be explained by the fact that E. coli ATCC 25922 and E. faecalis ATCC 29212 are not marine strains, and thus the apparent negative effect of EMF on their viability shown here can be assigned to the high salinity of the growth medium. Based on this, the authors deduce that exposure of 1,5 and $10 \mathrm{~min}$ to 50 $\mathrm{Hz}$ electromagnetic field of $0.25 \mathrm{~T}$ does not affect the viability of E. coli or E. faecalis.

Various non-thermal effects of EMF on bacteria such as bactericidal effects and effects on bacterial growth, bacterial DNA, cell morphology, as well as sensitivity to antibiotics, have been reported [25], furthermore, the effect of $50 \mathrm{~Hz}, 0.5 \mathrm{mT}$ ELFEMF applied for $6 \mathrm{~h}$ on E. coli (ATCC 25922) and E. faecalis (ATCC 29212) was also noted [13]. Different studies of low frequency magnetic fields on $E$. coli growth found in literature indicate that a negative effect increases with the time of exposure $[6,1$, 18,26 ], but other [5] suggest that the field effect is the greatest in the first few hours and then decreases implying an adaptive response of the exposed cells to field stress. In addition, some authors also observed an increase in cell viability in exposed samples [3], while others reported both stimulatory and

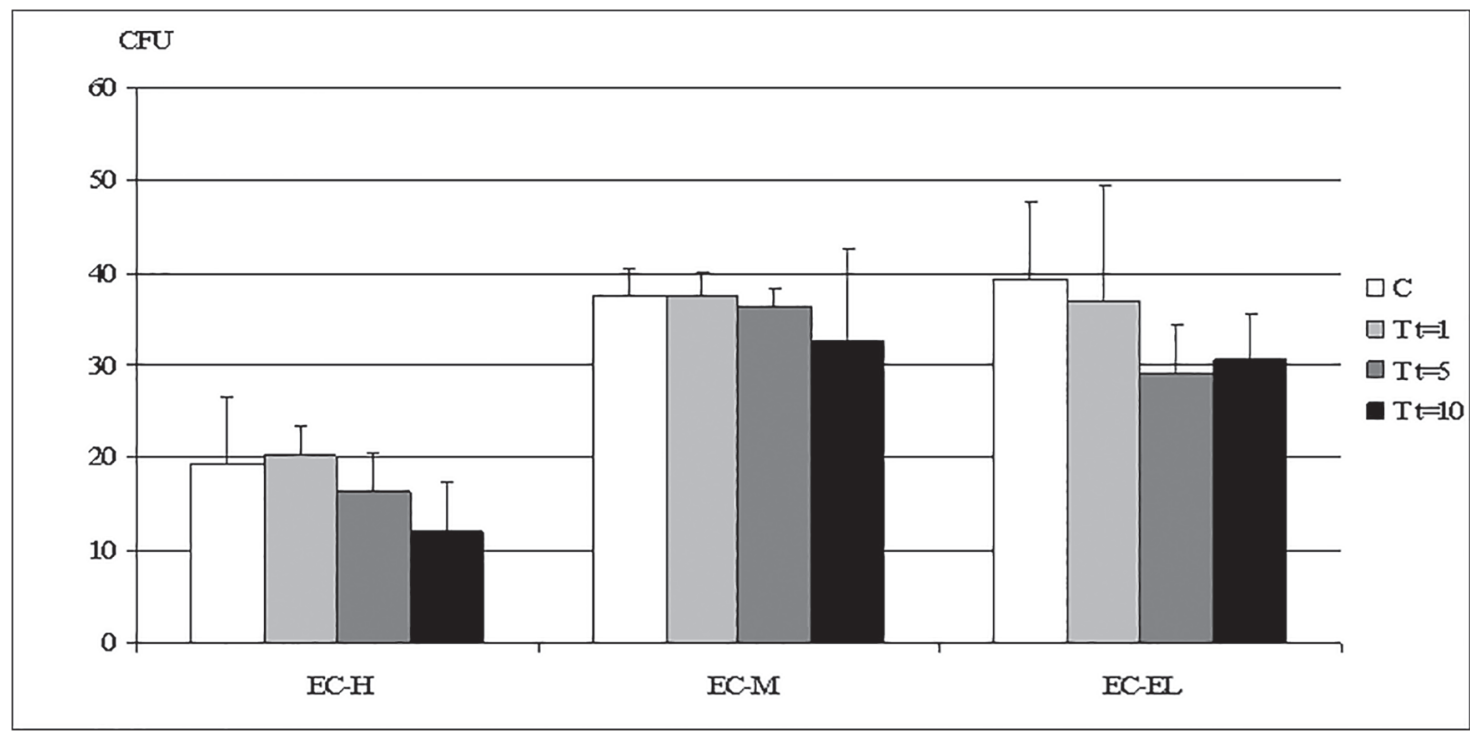

Figure 3 Escherichia coli CFU numbers in different growth media. The CFU were enumerated in control samples (C) and in the treated samples after $1(\mathrm{Tt}=1), 5(\mathrm{Tt}=5)$ and $10(\mathrm{Tt}=10)$ minutes of exposure to the $50 \mathrm{~Hz}$ electromagnetic field of $0.25 \mathrm{~T}$ in $(\mathrm{EC}-\mathrm{H})$, moderate (EC-M) and extremely low (EC-EL) conductivity media.

Slika 3. Broj izraslih kolonija (BIK) bakterije Escherichia coli u različitim uzgojnim medijima. BIKje prebrojavan u kontrolnim uzorcima (C) iu tretiranim nakon $1(T t=1), 5(T t=5)$ i 10 ( $T t=10)$ minuta izlaganja 50 Hz electromagnetskom polju 0.25T u mediju jake (EC-H), srednje (EC-M) iekstremno niske (EC-EL) vodljivosti. 


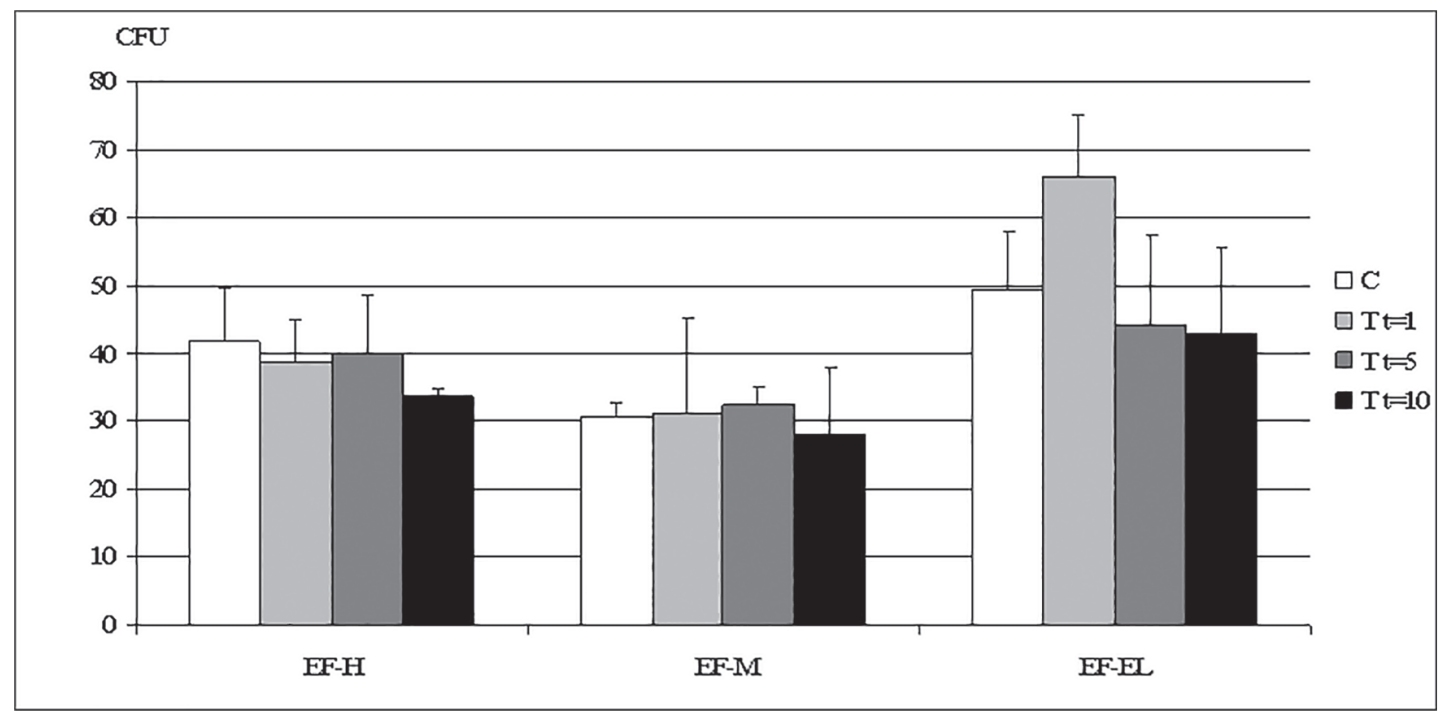

Figure 4 Enterococcus faecalis CFU numbers in different growth media. The CFU were enumerated in control samples (C) and in the treated samples after $1(\mathrm{Tt}=1), 5(\mathrm{Tt}=5)$ and $10(\mathrm{Tt}=10)$ minutes of exposure to the $50 \mathrm{~Hz}$ electromagnetic field of $0.25 \mathrm{~T}$ in high (EF-H), moderate (EF-M) and extremely low (EF-EL) conductivity media.

Slika 4. Broj izraslih kolonija (BIK) bakterije Enterococcus faecalis u različitim uzgojnim medijima. BIKje prebrojavan u kontrolnim uzorcima (C) i u tretiranim nakon 1 ( $T t=1), 5(T t=5)$ i 10 ( $T t=10)$ minuta izlaganja $50 \mathrm{~Hz}$ electromagnetskom polju $0.25 \mathrm{~T}$ u mediju jake $(E F-H)$, srednje (EF-M) i ekstremno niske (EF-EL) vodljivosti.

inhibitory impact of $50 \mathrm{~Hz}$ pulsed electromagnetic fields on E. coli (ATCC 25922) under low and high flow conditions [23]. Results of some experiments indicated that the survivability of E. coli cells suspended in phosphate buffer solution decreased with magnetic field intensity and treatment time, especially when the magnetic intensity of $160 \mathrm{mT}$ at frequency of $62 \mathrm{kHz}$ for a period of $16 \mathrm{~h}$ was applied [16]. It has also been demonstrated that an electromagnetic wave irradiation for $5 \mathrm{~s}$ at $500-1000 \mathrm{kHz}$ has bactericidal activity against several oral bacterial pathogens including E. faecalis [32]. In addition, several studies of extremely high frequencies EMF effect on Enterococcus hirae resulted in a decreased specific growth rate, but suggesting the differences in mechanisms of action $[20,30,11]$.

\section{CONCLUSION / Zaključak}

The viability of $T$. suecica was adversely affected by a $10 \mathrm{~min}$ exposure to $50 \mathrm{~Hz}$ EMF of $0.25 \mathrm{~T}$ only in the extremely-low conductivity growth medium, while all applied magnetic treatment did not affect the viability of E. coli (ATCC 25922) or E. faecalis (ATCC 29212). These results imply that exposure to $50 \mathrm{~Hz}$ EMF of $0.25 \mathrm{~T}$ is not suitable for inactivation of selected microorganisms in such a short exposure time and in a high conductivity media such as seawater. Considering many contrary findings of EMF effects on various microorganisms, we strongly suggest more research with higher and/or varying frequencies in order to have the maximum effect that can cause damage to cells because of EMF's obvious advantages over other methods for inactivation of microorganisms.

\section{ACKNOWLEDGEMENTS / Zahvale}

This work was carried out under a research contract from Ministry of Science, Education and Sport (TP-01/0275-01). The authors are grateful to the staff of Dubrovnik Hydro Power Plant for design and construction of the treating device, The Department of Environmental Health, Public Health Institute of the Dubrovnik - Neretva County for providing us with bacteria and The Mariculture Business and Innovation Centre of the University of Dubrovnik for providing us with marine microalgae. We thank Mr. Ivo Barač for helpful discussions and support during experiments and Ms. Ivana Bratoš for her help with English language. A special thanks goes to professor Martin Dadić, PhD, from The Department of Electrical Engineering Fundamentals and Measurements of The Faculty of Electrical Engineering and Computing of The University of Zagreb for performing the magnetic induction measurements. We dedicate this paper to late dr. sc. Josip Lovrić, professors emeritus of the University of Dubrovnik.

\section{REFERENCES / Literatura}

[1] Bayır, E.; Bilgi, E.; Şendemir-Ürkmez, A.; Hameş-Kocabaş, E. E. The effects of different intensities, frequencies and exposure times of extremely lowfrequency electromagnetic fields on the growth of Staphylococcus aureus and Escherichia coli O157:H7. Electromagnetic biology and medicine. 2015 Vol 34, No 1, pp. 14-18. https://doi.org/10.3109/15368378.2013.853671

[2] Carlton, J. T.; Geller, J. B. Ecological roulette: the global transport of nonindigenous marine organisms. 1993. Science, No 261, pp.78-82.

[3] Cellini, L.; Grande, R.; Di Campli, E.; Di Bartolomeo, S.; Di Giulio, M.; Robuffo, I.; Trubiani, O.; Mariggiò, M. A. Bacterial response to the exposure of $50 \mathrm{~Hz}$ electromagnetic fields. Bioelectromagnetics. 2008. Vol 29 No 4, pp. 302-311. https://doi.org/10.1002/bem.20391

[4] David, M.; Gollasch, S. Ballast water management systems for vessels. In David, M., Gollasch, S. (Eds.) Global maritime transport and ballast water management: Issues and solutions. 2015. Book Series: Invading Nature - Springer Series in Invasion Ecology, Vol. 8, pp. 109-132. https://doi. org/10.1007/978-94-017-9367-4_6

[5] El-Sayed, A. G.; Magda, H. S.; Eman, Y. T.; Mona, H. I. Stimulation and control of E. coli by using an extremely low frequency magnetic field. Romanian Journal of Biophysics. 2006. Vol. 16, No 4, pp. 283-296.

[6] Fojt, L.; Ludek, S.; Vladimır, V.; Šmarda, J. Comparison of the low-frequency magnetic field effects on bacteria Escherichia coli, Leclercia adecarboxylata and Staphylococcus aureus. Bioelectrochemistry. 2004. No 63, pp. 337-341. https://doi.org/10.1016/j.bioelechem.2003.11.010

[7] Forrest, L. W. Method for the magnetic inhibition of Protista. U.S. Patent 5248437 filed Dec. 19, 1990, and issued Sep. 28, 1993. United States Patent and Trademark Office, Washington, US. 1991.

[8] Foster, K. R.; Schwan, H. P. Dielectric properties of tissues and biological materials: a critical review. Critical reviews in biomedical engineering. 1989. Vol. 17, No 1, pp. 25-104.

[9] Garvey, M.; Moriceau, B.; Passow, U. Applicability of the FDA assay to determine the viability of marine phytoplankton under different environmental 
conditions. Marine Ecology Progress Series. 2007. No 352, pp.17-26. https://doi. org/10.3354/meps07134

[10] Hebner, R. E., Davey, K.; Werst, M. D.; Connelly, R. Electromechanical lysing of algae cells. U.S. Patent 20120021481 filed Jul. 20, 2010, and issued Jan. 26, United States Patent and Trademark Office, Washington, US. 2012.

[11] Hovnanyan, K.; Kalantaryan, V.; Trchounian, A. The distinguishing effects of lowintensity electromagnetic radiation of different extremely high frequencies on Enterococcus hirae: growth rate inhibition and scanning electron microscopy analysis. Letters in applied microbiology. 2017. Vol. 65, No 3, pp. 220-225. https:// doi.org/10.1111/lam.12764

[12] Hunt, R. W, Zavalin, A. Bhatnagar, A.; Chinnasamy, S.; Das, K. C. Electromagnetic biostimulation of living cultures for biotechnology, biofuel and bioenergy applications. International Journal of Molecular Sciences. 2009. No 10, pp. 45154558. https://doi.org/10.3390/ijms10104515

[13] Inhan-Garip, A., Burak, A., Zafer, A.; Dilek, A.; Ozaydin, A. N.; San, T. Effect of extremely low frequency electromagnetic fields on growth rate and morphology of bacteria. International journal of radiation biology. 2011. Vol. 87, No 12, pp. 1155-1161. https://doi.org/10.3109/09553002.2011.560992

[14] Jochem, F. J. Dark survival strategies in marine phytoplankton assessed by cytometric measurement of metabolic activity with fluorescein diacetate. Marine Biology. 1999. No 135, pp. 721-728. https://doi.org/10.1007/s002270050673

[15] Johnston, J. A; Forrest, L. W; Wickham, C. P. Magnetic apparatus for controlling Protista in distillates. U.S. Patent 5055188 filed Nov. 1, 1981, and issued Oct. 8, 1991. United States Patent and Trademark Office, Washington, US. 1991.

[16] Li, M.; Qu, J. H.; Peng, Y. Z. Sterilization of Escherichia coli cells by the application of pulsed magnetic field. Journal of environmental sciences. 2004. Vol. 16, No 2 , pp. 348-352.

[17] Lloyd's Register. Ballast water treatment technologies and current system availability. 2012. http://www.lr.org/Images/BWT2012v2b_tcm155-242898.pdf. (Last accessed 01/2017).

[18] Mousavian-Roshanzamir, S.; Makhdoumi-Kakhki, A. The Inhibitory effects of static magnetic field on Escherichia coli from two different sources at short exposure time. Reports of biochemistry and molecular biology. 2017. No 5, pp. 112-116.

[19] Obermeier, A.; Matl, F. D.; Friess, W.; Stemberger, A. Growth inhibition of Staphylococcus aureus induced by low-frequency electric and electromagnetic fields. Bioelectromagnetics. 2009. Vol. 30, No 4, pp. 270-279. https://doi. org/10.1002/bem.20479

[20] Ohanyan, V.: Sarkisyan, H.; Tadevosyan, A.; Trchounian, A. The action of lowintensity extremely high frequency electromagnetic radiation on growth parameters for bacteria Enterococcus hirae. Biophysics. 2008. Vol. 53, No 5, pp. 406-408. https://doi.org/10.1134/S0006350908050151

[21] Panagopoulos, D. J., Messini, N.; Karabarbounis, A.; Philippetis, A. L.; Margaritis, L. $\mathrm{H}$. A mechanism for action of oscillating electric fields on cells. Biochemical and biophysical research communications. 2000. Vol. 272, No 3, pp. 634-640. https:// doi.org/10.1006/bbrc.2000.2746

[22] Panagopoulos, D. J.; Karabarbounis, A.; Margaritas, L. H. Mechanism for action of electromagnetic fields on cells. Biochemical and biophysical research communications. 2002. No 298, pp. 95-102. https://doi.org/10.1016/S0006291X(02)02393-8

[23] Piyadasa, C.; Yeager, T. R., Gray, S. R.; Stewart, M. B., Ridgway, H. F.; Orbell, J. D. Antimicrobial effects of pulsed electromagnetic fields from commercially available water treatment devices - controlled studies under static and flow conditions. Journal of chemical technology and biotechnology. 2018. Vol. 93, No 3, pp. 871-877. https://doi.org/10.1002/jctb.5442

[24] Reavie, E. D.; Cangelosi, A. A., Alinger, L. E. Assessing ballast water treatments: Evaluation of viability methods for ambient freshwater microplankton assemblages. Journal of Great Lakes research. 2010. No 36, pp. 540-547. https://doi.org/10.1016/j.jglr.2010.05.007

[25] Salmen, S. H. Non-thermal biological effects of electromagnetic field on bacteria-A review. American Journal of Research Communication. 2016. Vol. 4, No 6, pp. 16-28.

[26] Selamat, R.; Abustan, I.; Arshad, M. R.; Kamal, N. H. M. Effect of low-frequency electromagnetic fields on the Escherichia coli growth for application in riverbank filtration. 2017. In: Aziz, H. A.; Abu Bakar B.H., Megat Johari, M. A Choong, K. K.; Yusoff, M. S.; Mohd Hasan, M. R.; Ramli, M. H.; Halim, H. (Eds), Proceedings of the International Conference of Global Network for Innovative Technology and AWAM International Conference in Civil Engineering 2017, AIP Conference Proceedings, Vol. 1892, 040011, AIP Publishing, Melville, New York. https://doi.org/10.1063/1.5005691

[27] Sullivan, M. J.; Sharma, R. V.; Wachtel, R. E.; Chapleau, M. W.; Waite, L. J., Bhalla, R. C., Abboud, F. M. Non-voltage-gated Ca2+ influx through mechanosensitive ion channels in aortic baroreceptor neurons. Circulation research. 1997. Vol. 80, No 6, pp. 861-867. https://doi.org/10.1161/01.RES.80.6.861

[28] Taylor, A., Rigby, G.; Gollasch, S.; Voight, M.; Hallegraeff, G.; McCollin, T.; Jelmert A. Preventive treatment and control techniques for ballast water. In: Leppäkoski, E.; Gollasch, S., Olenin, S. (Ed.) Invasive aquatic species of Europe. Distribution, impacts and management. Kluwer Academic Publishers, Dordrecht, Netherlands, 2002. pp. 484-507.https://doi.org/10.1007/978-94-015-9956-6_48

[29] Torgomyan, H.; Hovnanyan, K.; Trchounian, A. Escherichia coli growth changes by the mediated effects after low-intensity electromagnetic irradiation of extremely high frequencies. Cell biochemistry and biophysics. 2012. Vol. 65, No 3 pp. 445-454. https://doi.org/10.1007/s12013-012-9448-9

[30] Torgomyan, H.; Ohanyan, V.; Blbulyan, S.; Kalantaryan, V.; Trchounian, A Electromagnetic irradiation of Enterococcus hirae at low intensity 51.8 and $53.0-\mathrm{GHz}$ frequencies: changes in bacterial cell membrane properties and enhanced antibiotics effects. Federation of European microbiological societies microbiology letters. 2012. Vol. 329, No 2, pp.131-137.

[31] Tsolaki, E.; Diamadopoulos, E. Technologies for ballast water treatment: a review. Journal of chemical technology and biotechnology. 2010. Vol. 85, No 1, pp. 19-32. https://doi.org/10.1002/jctb.2276

[32] Yumoto, H.; Tominaga, T., Hirao, K.; Kimura, T.; Takahashi, K.; Sumitomo, T.; Bando, N.; Matsuo, T. Bactericidal activity and oral pathogen inactivation by electromagnetic wave irradiation. Journal of applied microbiology. 2012. No 113, pp. 181-191. https://doi.org/10.1111/j.1365-2672.2012.05307.x 